\title{
A revision of the Indo-Pacific fish genus Caragobius (Gobiidae: Amblyopinae)
}

\author{
EDWARD O. MURDY ${ }^{1} \&$ KOICHI SHIBUKAWA ${ }^{2}$ \\ ${ }^{1}$ National Science Foundation, 4201 Wilson Blvd., Arlington, Virginia 22230, USA (current address: National \\ Sea Grant Office, 1315 East-West Highway, R/SG, Silver Spring, Maryland 20910, USA) \\ ${ }^{2}$ Department of Zoology, National Science Museum, 3-23-1 Hyakunin-cho, Shinjuku-ku, Tokyo 169-0073, \\ Japan
}

\begin{abstract}
The Indo-West Pacific gobiid genus Caragobius Smith and Seale is revised and defined. Caragobius has been frequently considered a synonym of Brachyamblyopus; however, Caragobius is unique within the Amblyopinae in having: 3-7 (typically 4-6) anal-fin pterygiophores anterior to first hemal spine; fifth hypural absent; and ribs lacking on 3rd precaudal vertebra. Caragobius comprises two species: C. rubristriatus, known from northern Australia, and C. urolepis, known from India, Thailand, Indonesia, the Philippines, Taiwan, Japan, and Fiji. Images of both species are provided. Caragobius is compared to Brachyamblyopus and Trypauchen-Group members.
\end{abstract}

Key words: Amblyopinae, Gobiidae, Trypauchen Group, Caragobius

\section{Introduction}

Caragobius typhlops was described as a new genus and species by Smith and Seale (1906) from five specimens collected from the Rio Grande near Cotabato, Mindanao, Philippines. Smith and Seale's description of Caragobius was rather unremarkable except that they mentioned their specimens possessed "a small pore above each gill-opening which opens into a cavity separate from gill-cavity"; among gobioid fishes, this character is unique to Amblyotrypauchen, Ctenotrypauchen, Trypauchen, and Trypauchenichthys [members of the Trypauchen Group of Murdy (2002) as modified from Birdsong et al. (1988)]. Smith and Seale (1906) did state that Caragobius was related to Trypauchen but differed in "squamation, teeth, eyes, etc.".

Herre (1927) examined Smith and Seale's specimens of Caragobius typhlops and determined that the pore above the gill cavity [shallow pouch along the dorsal edge of the operculum] was not present in any of the specimens. Herre (1927) surmised that Smith 
and Seale (1906) may have confused a tear in the skin with a pore. Koumans (1940) concurred with Herre's assessment and allied Caragobius with his Taenioininae (Koumans, 1931), a group comprising eight genera, but none of the Trypauchen-Group genera named above. Furthermore, Koumans stated that Caragobius was probably synonymous with Brachyamblyopus, one of the members of his Taenioininae. Subsequently, Koumans (1953) provisionally synonymized Caragobius with Brachyamblyopus.

Birdsong et al. (1988) placed Caragobius in their Trypauchen Group, an assemblage that did not include Brachyamblyopus, but did include Amblyotrypauchen, Trypauchen, and Trypauchenichthys. This group was defined by its shared possession of a pterygiophore formula (PF) of 3-1221 that is unique among gobiid fishes. Murdy and Shibukawa (2002) reported that the holotype of Amblyopus brachysoma Bleeker (1853), the type for the genus Brachyamblyopus, has a $\mathrm{PF}=3-12210$ and, thus, correctly belongs in the Taenioides Group of Birdsong et al. (1988).

Among Trypauchen-Group members, all but Caragobius and Karsten possess a shallow pouch along the dorsal edge of the operculum ("blind sac-shaped depression" of Hora, 1924); the function of this pouch is not known. Murdy (2002) proposed that Caragobius is the sister group to all other Trypauchen-Group members and Karsten is the sister group to all Trypauchen-Group members that possess an opercular pouch.

As a revision of Caragobius has never been published, the objectives of this paper are to: elucidate characters to distinguish Caragobius from other amblyopines particularly other Trypauchen-Group members; provide a key to species of Caragobius and a description of each; and present information about the distribution and ecology of Caragobius species.

\section{Materials and methods}

All measurements are straight-line distances made with dial calipers and recorded to the nearest 0.1 millimeter. Standard length (SL) is used throughout except where noted as total length (TL). Methods of measurements and counts follow Murdy (1989), and Murdy and Shibukawa (2001).

The vertebral count is separated into precaudal and caudal counts, the latter including the urostylar complex. Counts of axial skeletal features (i.e., vertebrae, ribs, pterygiophores, and epurals) were taken from radiographs. The methods of Birdsong et al. (1988) were used in describing the relationship between the spinous dorsal-fin pterygiophores and the underlying vertebrae.

Institutional abbreviations are as listed in Leviton et al. (1985). The total number of specimens examined and size range follow each catalog number. Data referring to type specimens, including those pertaining to synonyms, are listed by specific name and type category. 
Caragobius Smith and Seale, 1906: 418 (type species: Caragobius typhlops Smith and Seale, 1906, by original designation and monotypy)

Trypauchenophrys Franz, 1910: 68 (type species: Trypauchenophrys anotus Franz, 1910, by original designation and monotypy).

Caragobioides Smith, 1945: 571 (type species: Caragobius geomys Fowler, 1935, by original designation and monotypy).

Included Species. Caragobius comprises two species, C. rubristriatus and C. urolepis.

Diagnosis. The genus is unique within the Amblyopinae in having: 3-7 anal-fin pterygiophores anterior to first hemal spine (AP); fifth hypural absent; and ribs lacking on 3rd precaudal vertebra. The other features useful in distinguishing it from all other Trypauchen-Group members are: pectoral fins broadly rounded, symmetrical dorsoventrally; head slightly depressed; no fang-like teeth; no opercular pouch; eyes rudimentary; and pelvic fins rounded.

Description. Total dorsal-fin elements 36-52; first dorsal fin with six flexible spines; first element of second dorsal fin segmented, or segmented and branched, all others segmented and branched rays; dorsal-fin base long and broadly joined with caudal fin. A short, longitudinal fleshy ridge anterior to dorsal fin. Total anal-fin elements $31-45$, first element spinous or segmented, or segmented and branched, all other elements segmented and branched; anal-fin height approximately equal to second dorsal-fin height; anal-fin membrane broadly joined with caudal fin. Pectoral-fin rays 16-20, pectoral fin short and rounded posteriorly; all pectoral-fin rays segmented and branched, except, occasionally, dorsalmost and/or ventralmost just segmented. Pelvic-fin rays I, 5, with well developed frenum and connecting membrane forming cup-shaped disc. Caudal fin long and pointed, with $12-15$ segmented rays (typically 13 in a $7+6$ arrangement), and $10-12$ branched rays (typically 11 in a $6+5$ arrangement). Ray associated with epural typically is very short and bifid, ray associated with ultimate hemal spine typically is very short and simple. Procurrent rays typically absent; when present, are rudiments.

Head slightly depressed with body compressed. Scales cycloid, anteriormost small, embedded, non-imbricated; posteriormost larger and slightly overlapping.

Upper and lower jaws with two rows of slender, sharp-tipped canine teeth that are slightly curved inward. Outer-row teeth slightly larger than those of inner row; outer-row teeth of lower jaw approximately equal in size to those of upper jaw; 10-27 teeth in outer row of upper jaw; 12-28 teeth in outer row of lower jaw. No palatine or vomerine teeth present.

Mouth large and oblique, jaws terminating posteriorly at the vertical with, or just anterior to, posterior naris. Tongue thin, tip free from floor of mouth. Isthmus moderate to broad. No barbels present.

Eye rudimentary, but distinct, covered by skin, slightly smaller than diameter of posterior naris. Posterior naris located immediately anteromedial to eye; anterior naris at tip of a very short flap that slightly overhangs upper jaw. 
Cephalic sensory canals and pores absent. Sensory papillae present on head and anteriorly on body, but difficult to observe without magnification. Sensory papillae on head scattered, not forming a discernible pattern except for those along mandible, which follow the jaw line. Sensory papillae on body represented by a longitudinal, midlateral raised fold of tissue with smaller dermal ridges radiating dorsally and ventrally. Sensory papillae lacking on posterior $30-40 \%$ of body.

Gill rakers low, fleshy, and unossified; gill opening narrow, extending only the height of the pectoral-fin base.

Osteology. Spinous dorsal-fin pterygiophore formula 3-1221, rarely 3-1221+1 or 3$1311+1$ [in these latter two, the sixth spine shares its interneural space with the first pterygiophore associated with the first dorsal-fin soft ray]. Precaudal vertebrae 10, rarely 9 or 11; caudal vertebrae 18-22 or 25-27. Pterygiophore of the second soft dorsal-fin ray (typically the posteriormost pterygiophore inserting in $7^{\text {th }}$ interneural space) has a middle radial. Epurals 2. Basihyal spatulate. Symplectic with a posteriorly directed arm that cartilaginously joins the hyomandibula; this arm creates a small oblong-shaped gap between dorsal aspect of symplectic and the hyomandibula. Dorsoposterior tip of metapterygoid in contact with inner surface of hyomandibula. Infrapharyngobranchial 2 lacking. Uncinate process on epibranchial 3 present. Frontal crest present but low. Four pectoral fin radials with three fossa, largest one between radials 2-3, smallest between 1-2. Long dorsallydirected flange anteroventrally on subopercle. Atlas with well developed parapophyses, in contact with first epineural. Epineurals present from 1 st precaudal vertebra through $9^{\text {th }}$ to $12^{\text {th }}$ caudal vertebra. Well-developed ribs on 4th through 9th precaudal vertebrae, ribs on $10^{\text {th }}$ precaudal vertebra slightly reduced. Epineurals fused with ribs on precaudal vertebrae 4-8. In one cleared \& stained specimen from Fiji (USNM 241794), middle radial of ultimate pterygiophore in anal and dorsal fins forked; all other middle radials of anal and dorsal fin pterygiophores simple and not forked. Hypural 5 absent.

Comparison with Brachyamblyopus. As mentioned above, Caragobius has been confused with Brachyamblyopus. However, Caragobius is easily distinguished from Brachyamblyopus as follows: in C. rubristriatus, scales extending from the vertical with $3^{\text {rd }}$ or $4^{\text {th }}$ dorsal-fin spine to caudal peduncle, whereas in C. urolepis, no scales ventral to spinous dorsal fin (vs. scales extending from predorsal area to caudal peduncle in Brachyamblyopus); total elements in anal fin 31-45 in Caragobius (vs. 28-31 in Brachyamblyopus); jaw length/SL 0.048-0.070 in Caragobius (vs. 0.070-0.081 in Brachyamblyopus); no interneural gap in Caragobius (vs. interneural gap present in Brachyamblyopus); $\mathrm{AP}=3-7$ (vs. AP=2); 18 or more caudal vertebrae (vs. 16 caudal vertebrae); and first ribs on precaudal vertebra 4 (vs. first ribs on precaudal vertebra 3 ). 
1a. Total elements in dorsal fin 43 or fewer, typically $38-40$; total elements in anal fin 36 or fewer, typically 32-35; anal-fin pterygiophores anterior to first hemal spine 4-7, typically 5 or 6 ; caudal vertebrae $18-22$, typically 20 or 21 ; longitudinal scale rows extend from just posterior to mid-body to caudal peduncle. (India, Thailand, Indonesia, Japan, Philippines, Fiji) C. urolepis

1b. Total elements in dorsal fin 43 or more, typically 48-50; total elements in anal fin 35 or more, typically 40-43; anal-fin pterygiophores anterior to first hemal spine 3-5, typically 4; caudal vertebrae 25-27; longitudinal scale rows extend from just posterior to distal tip of pectoral fin to caudal peduncle. (northern Australia) C. rubristriatus

Caragobius urolepis (Bleeker, 1852)

(Figs.1-2, Tables 1-2)

Amblyopus urolepis Bleeker, 1852: 581 (type locality, Palembang, Sumatra, Indonesia).

Caragobius typhlops Smith and Seale, 1906: 81, figured (type locality, Rio Grande, Mindanao, Philippines).

Trypauchenophrys anotus Franz, 1910: 68, pl. 9, fig. 77 (type locality, Fukuura, Japan).

Taenioides chilkensis Hora, 1923: 757 (type locality, channel off Barhampur Island, Chilka Lake, Orissa, India).

Brachyamblyopus olivaceus Herre, 1927: 329 (type locality, Negros Oriental, Philippines).

Caragobius geomys Fowler, 1935: 161, figs. 129-130 (Bangkok, Thailand).

Nudagobioides monserrati Roxas and Ablan, 1940: 309, pl. 8 (Lingayan Gulf, Luzon, Philippines). Brachyamblyopus urolepis: Koumans, 1941: 299 (new combination).

Material examined. (Total of 104 specimens, 15.1-71.5 mm SL). Thailand: Central Bangpakong River: USNM 265010, 1:62.6. Bangkok: ANSP 63078, holotype of Caragobius geomys Fowler, 56.0. Sumatra, Indonesia: Palembang, probably the Musi River: RMNH 4807, lectotype of Amblyopus urolepis Bleeker, 61.5; RMNH 34799, paralectotype of Amblyopus urolepis Bleeker, 58.9. Irian Jaya, Indonesia: Bintuni River: WAM P. 29953008, 2:19.0-23.5. Sabah, Malaysia: Tawau River: NSMT-P 49332, 3: 39.8-51.1. Mindanao, Philippines: near the mouth of the Rio Grande: USNM 55619, holotype of Caragobius typhlops Smith and Seale, 56.6; USNM 126384, paratype of Caragobius typhlops Smith and Seale, 50.8; USNM 151316, 1:56.0. Siquijor Island, Philippines: tidal inlet at Sabanj: USNM 243403, 45:32.9-71.5. Negros Oriental, Philippines: Canauay River, about $75 \mathrm{~m}$ upstream from mouth in tidal mangrove pool: USNM 243404, 32:23.2-58.7. Viti Levu, Fiji: mudflat on north side of Nangara Island: USNM 241794, 15:15.1-34.4.

Description. As for genus except as follows. Total elements in dorsal fin 36-43 (mean $=39.2$ ); total elements in anal fin 31-36 (mean = 33.1), first element segmented, or segmented and branched; pectoral-fin rays 17-20 (mean = 18.4); anal-fin pterygiophores preceding the first hemal spine (AP) 4-7 (mean = 5.4); caudal vertebral count 18-22 (mean = 


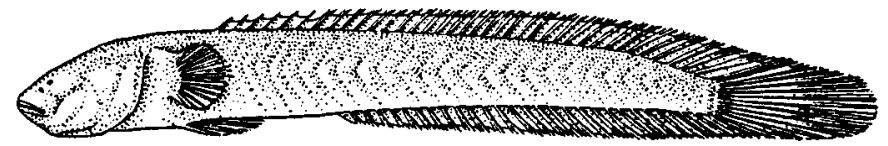

FIGURE 1. Taenioides chilkensis (= Caragobius urolepis) from Hora 1924

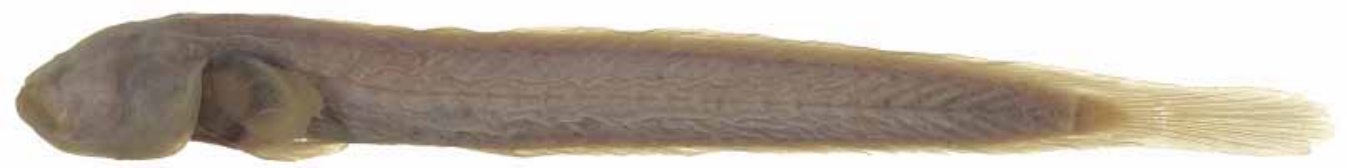

FIGURE 2. Caragobius urolepis, USNM 243403, $59.0 \mathrm{~mm}$ SL, male, Siquijor Island, Philippines. Image by Sandra J. Raredon.

Scales only on posterior 25-30\% of body, remainder of body and head lacking scales. 18-27 teeth on outer row of upper jaw; 12-28 teeth on outer row of lower jaw. Jaws terminating posteriorly at the vertical just anterior to posterior naris.

Anterior nares much closer together than posterior nares.

Color when fresh. No fresh specimens were available. Bleeker (1852) stated that his specimen had a greenish body with yellowish fins. Roxas and Ablan (1940) described Nudagobioides monserrati as yellowish in life. The photograph of a presumably freshly dead Brachyamblyopus (= Caragobius) urolepis in Kottelat et al. (1993) depicts a bluish gray head, a creamy white body, the pectoral-fin base blackish blue, and the fins translucent.

Color in alcohol. Head and body uniformly tannish brown with translucent fins. Some specimens with a brownish black area along posterior edge of pectoral-fin base; the color derives from a prominent blood vessel.

Preserved specimens were uniformly yellowish white according to Smith and Seale (1906), whereas Hora (1923) stated that the body was olivaceous gray with whitish fins. Herre (1927) said that preserved specimens of Caragobius typhlops had a bluish gray head and yellowish body, which became whitish on belly and underside of head, and yellowish gray posteriorly. Brachyamblyopus olivaceous had a dusky olive-brown body, slightly pale head, and yellowish fins (Herre, 1927). As described by Fowler (1935), Caragobius geomys was drab and pale with shades of gray on the head and translucent fins. Three dusky gray lines were also present on C. geomys: one extending from the terminus of the maxilla and one dorsal and ventral to the pectoral fin. However, none of these gray lines was evident when the holotype of $C$. geomys was examined. 
TABLE. 1. Selected meristic values for species of Caragobius. For C. urolepis, condition in lectotype is underscored. Meristic values, except for pectoral-fin rays, are based on radiographs, and eight cleared and stained specimens of C. urolepis - two removed from USNM 241794; three from USNM 243403; and three from USNM 243404.

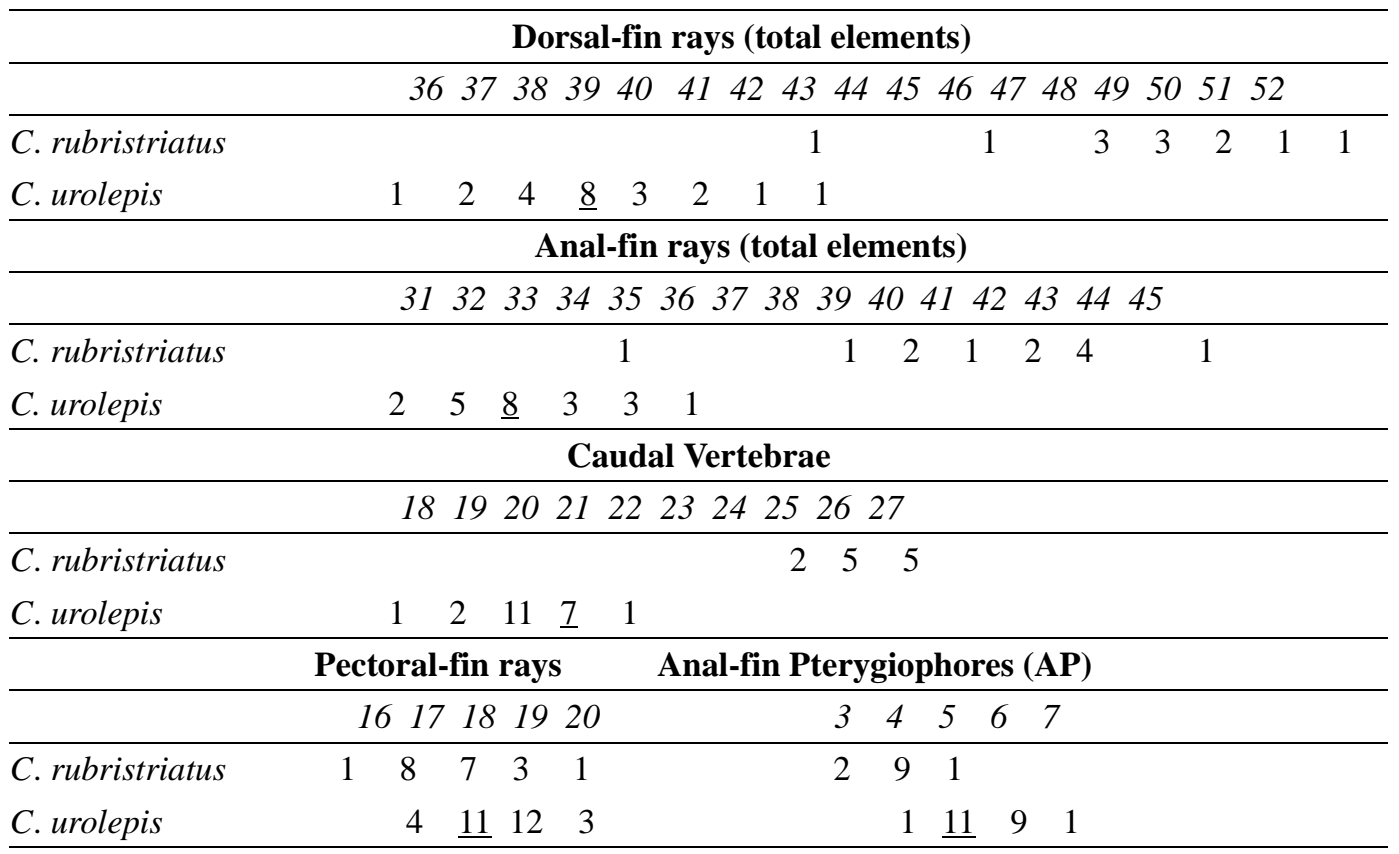

TABLE 2. Ranges and means of selected morphometric measures of Caragobius.

\begin{tabular}{|c|c|c|c|c|c|c|}
\hline \multirow[t]{2}{*}{ Morphometric measure } & \multicolumn{3}{|c|}{ C. urolepis } & \multicolumn{3}{|c|}{ C. rubristriatus } \\
\hline & $n$ & mean & range & $n$ & mean & range \\
\hline Standard length/TL & 12 & 0.824 & $0.794-0.891$ & 11 & 0.809 & $0.775-0.844$ \\
\hline Head length/SL & 12 & 0.197 & $0.172-0.230$ & 11 & 0.179 & $0.162-0.200$ \\
\hline Pelvic-fin length (PEL)/SL & 12 & 0.098 & $0.077-0.120$ & 11 & 0.097 & $0.079-0.125$ \\
\hline Pelvic-fin length/HL & 12 & 0.494 & $0.311-0.615$ & 11 & 0.547 & $0.463-0.750$ \\
\hline Pectoral-fin length/SL & 23 & 0.079 & $0.062-0.110$ & 21 & 0.076 & $0.054-0.100$ \\
\hline Pectoral-fin length/HL & 23 & 0.399 & $0.296-0.558$ & 21 & 0.426 & $0.298-0.603$ \\
\hline Pectoral-fin length/PEL & 23 & 0.824 & $0.627-1.125$ & 21 & 0.809 & $0.436-1.100$ \\
\hline Head width/SL & 12 & 0.126 & $0.091-0.157$ & 11 & 0.113 & $0.097-0.130$ \\
\hline Snout length/SL & 12 & 0.048 & $0.034-0.077$ & 10 & 0.043 & $0.035-0.050$ \\
\hline Jaw length/SL & 12 & 0.056 & $0.048-0.065$ & 10 & 0.064 & $0.052-0.070$ \\
\hline Interorbital width/SL & 12 & 0.039 & $0.031-0.055$ & 10 & 0.035 & $0.030-0.045$ \\
\hline Nape width/SL & 12 & 0.092 & $0.075-0.131$ & 10 & 0.086 & $0.072-0.102$ \\
\hline Body depth/SL & 12 & 0.112 & $0.101-0.124$ & 10 & 0.101 & $0.090-0.113$ \\
\hline Predorsal length/SL & 12 & 0.287 & $0.241-0.363$ & 10 & 0.248 & $0.211-0.281$ \\
\hline Prepelvic length/SL & 12 & 0.216 & $0.194-0.256$ & 10 & 0.189 & $0.169-0.220$ \\
\hline Preanal length/SL & 12 & 0.405 & $0.373-0.431$ & 10 & 0.401 & $0.376-0.432$ \\
\hline
\end{tabular}


Ecology. Akihito et al. (1984) reported that in Japan Brachyamblyopus anotus (=C. urolepis) inhabits soft mud bottoms near river mouths. Chen and Fang (1999) stated that C. urolepis constructs burrows in the muddy substrate and feeds on zooplankton and crustaceans.

Distribution. East coast of India (Hora, 1923), Thailand (Fowler, 1935), Indonesia (Bleeker, 1852), the Philippines (Herre, 1927), northward to Taiwan (Chen and Fang, 1999), southern Japan (Akihito et al. 1984) and eastward to Fiji. Specimens have only been examined from Thailand, Indonesia, the Philippines, and Fiji. Because C. urolepis is found in burrows in silty mud habitats, it is difficult to collect, which may help explain its relative paucity in museum collections.

Remarks. The original description of $C$. typhlops Smith and Seale (1906) was based on five specimens (2-2.5 inches, or 50.8-63.5 mm); the type (USNM 55619) was indicated, but no other catalogue numbers were provided. In his discussion of $C$. typhlops, Herre (1927) stated that seven specimens $(35-54 \mathrm{~mm})$ comprised the original collection. The National Museum of Natural History houses the holotype and one paratype (USNM 126384). Böhlke (1953) reported on the holotype and another paratype of C. typhlops (CAS-SU 20008). Although stating that there were four paratypes, Eschmeyer (1998) provided catalogue numbers for only two, USNM 126384 and CAS-SU 20008. The disposition of the other paratypes remains a mystery. One of the specimens examined for this study (USNM 151316, $56.0 \mathrm{~mm}$ SL) came from the type locality and its other collection information is similar to that of the holotype; USNM 151316 may represent one of the missing paratypes.

A radiograph of the holotype (SMF 7432) of Trypauchenophrys anotus Franz (1910) was examined. Based on the data gathered from the radiograph $(\mathrm{PF}=3-1221, \mathrm{AP}=6$, total dorsal-fin elements 38 , total anal-fin elements 33 , vertebrae $10+21$, no ribs on vertebra 3 ), we place this species in synonymy of $C$. urolepis. We question, however, the locality of the type (Fukuura, approximately $35^{\circ} \mathrm{N}$ ); no other conspecifics have been collected or reported this far north in Japan. Akihito et al. (1984) reported Brachyamblyopus anotus (= C. urolepis) only from two of the southernmost islands in Japan (Ishigakijima and Iriomotejima, both islands at approximately $\left.24^{\circ} \mathrm{N}\right)$.

The syntypes of Taenioides chilkensis Hora (1923) were not examined; according to Eschmeyer (1998) they reside at the Zoological Society of India (ZSIF10385/1). Synonymy was based on the original description and figure. The description of $T$. chilkensis clearly indicates distinctive features of Caragobius (i.e., continuous dorsal and anal fins, minute eyes, head deeper than body, short, muscular pectoral fins, and pelvic fins longer than pectoral fins), whereas the meristic values for the dorsal fins (37-38) and morphometric measures (as \% of SL) for pelvic-fin length, pectoral-fin length, head length, and snout length are consistent with $C$. urolepis. The figure accompanying the description also served to confirm the synonymy and is reprinted here as Figure 1. Hora (1924) reconsidered the generic placement of Taenioides chilkensis and reassigned it to Trypauchenoph- 
yrs. Hora (1924) also provided a count of caudal vertebrae (20) for T. chilkensis that is consistent with Caragobius urolepis.

As type material for Brachyamblyopus olivaceus Herre (1927) and Nudagobioides monserrati Roxas and Ablan (1940) was destroyed during World War II, our synonymy is based on the original description and figure. For his new species, B. olivaceous, Herre (1927) described features of Caragobius (i.e., minute eyes, no chin barbels, broadly rounded pectoral fins, no sensory pores or ridges on head, and scales present only near caudal-fin base) and the total number of dorsal and anal fin elements (37-39 and 30-33, respectively) were consistent with $C$. urolepis. The accompanying figure also helped confirm the synonymy. Similarly, Roxas and Ablan (1940) provided descriptive features of Caragobius (i.e., scales only present on precaudal region, eyes very small and dorsally placed, pectoral fin short, broad, and round, dorsal and anal fins continuous with caudal fin) as well as the count of dorsal-fin elements (38) that support synonymization of Nudagobioides monserrati with $C$. urolepis. The figure of $N$. monserrati also supports this synonymy even though the precaudal region and caudal fin were imprecisely rendered.

Koumans (1953) provisionally synonymized Caragobius geomys Fowler (1935) with Brachyamblyopus urolepis $[=$ C. urolepis]. The holotype (ANSP 63078) of C. geomys was examined and a radiograph made. The examination of the holotype confirmed the presence of scales only on the posterior $25 \%$ of the body, which is diagnostic for C. urolepis. The data gleaned from the radiograph $(\mathrm{PF}=3-1221, \mathrm{AP}=5$, total dorsal-fin elements 39 , total anal-fin elements 32 , vertebrae $10+20$, no ribs on vertebra 3 ), are consistent with $C$. urolepis. The morphometric measures are consistent as well. Therefore, we concur with Koumans (1953) and place this species in synonymy of $C$. urolepis.

Caragobius rubristriatus (Saville-Kent, 1889)

(Fig. 3, Tables 1-2)

Amblyopus rubristriatus Saville-Kent, 1889: 235 (type locality, Cambridge Gulf, Western Australia, Australia).

Taenioides rubristriatus: McCulloch and Ogilby, 1919: 207 (new combination).

Brachyamblyopus rubristriatus: Larson and Williams, 1997: 372 (new combination).

Material examined. (Total of 18 specimens, 36.8-102.8 mm SL). Western Australia, Australia: Prince Regent River: WAM P.25035-003, 4:45.1-64.3. Northern Territory, Australia: East Alligator River: AMS I.32102001, 1:65.0; King Creek: AMS I.21221-001, 3:81.4102.8; Roper River near Gulf of Carpentaria: NTM S. 14017-005, 1:75.1. Queensland, Australia: west of Cape York: AMS I.15557-230, 9:36.8-93.6.

Description. As for genus except as follows. Total elements in dorsal fin 43-52 (mean $=48.6)$; total anal-fin elements 35-45 (mean $=41.3)$, first element spinous or segmented; pectoral-fin rays $16-20($ mean $=17.8)$; anal-fin pterygiophores preceding the first hemal 

$0.844($ mean $=0.809)$; pelvic-fin length $(\mathrm{PEL}) / \mathrm{HL} 0.463-0.750($ mean $=0.547)$; predorsal length/SL 0.211-0.281 (mean $=0.248)$.

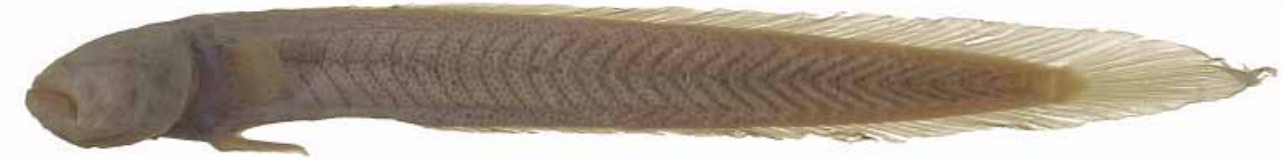

FIGURE 3. Caragobius rubristriatus, AMS I. 21221-001, $81.4 \mathrm{~mm}$ SL, female, King Creek, Northern Territory, Australia. Image by Sandra J. Raredon.

Scales absent from anteriormost $30 \%$ of head and body, scales extending posteriorly from the vertical with $3^{\text {rd }}$ or $4^{\text {th }}$ dorsal-fin spine.

10-23 teeth in outer row of upper jaw; 14-25 teeth in outer row of lower jaw. Jaws terminating posteriorly at a vertical with posterior naris. Anterior nares slightly closer together than posterior nares.

Color when fresh. No fresh specimens were available, however Saville-Kent (1889) stated that this fish was rosy pink in life with a carmine longitudinal stripe and smaller carmine streaks branching from the longitudinal stripe that delineated the outlines of the myotomes. Its fins were yellowish.

Color in alcohol. Head and body tannish; fins translucent. In many specimens, prominent blood vessel gives the appearance of a brownish blotch dorsal to the pectoral-fin base coursing along the anterior pectoral-fin base.

Ecology. The original description (Saville-Kent, 1889) was based on a single specimen collected with a dredge in Cambridge Gulf from a depth of approximately $9 \mathrm{~m}$. According to Saville-Kent, a second fish was brought to the surface by the same method near Darwin but the fish escaped back into the water.

Distribution. Western Australia, Northern Territory, and Queensland, Australia. In comparison to its congener, the distribution of $C$. rubristriatus is very limited, extending across northern Australia from the Prince Regent River to the Gulf of Carpentaria.

Remarks. The type for C. rubristriatus may still exist, but its whereabouts are unknown (Eschmeyer, 1998). Meristic values and the figure provided in the original description serve to distinguish this species and, thus, the designation of a neotype is not warranted at this time.

The original description contains an error with respect to the count of anal-fin rays; the count for the anal fin is given as 6/44, which is the same as for the dorsal fin (Saville-Kent, 1889). Based on radiographs of 12 specimens, no specimen had more than one spine in the anal fin and none had more than 45 total anal-fin elements. We believe that SavilleKent mistakenly repeated the count of dorsal-fin elements for the anal fin. 
Numerous individuals aided this study in the loan and exchange of specimens, or in other diverse ways. For their contributions we are grateful: Susan Jewett (USNM), Mike Littman (ANSP), Lisa Palmer (USNM), Sandra J. Raredon (USNM), Mark Sabaj (ANSP), Shirleen Smith (USNM), Martien van Oijen (RMNH), Lynne Parenti (USNM), and Hans Zetzsche (SMF).

\section{References}

Akihito, Prince, Hayashi, M., Yoshino, T., Shimada, K., and Senou, H. (1984) Suborder Gobioidei,. In: Masuda, H., Amaoka, K., Araga, C., Uyeno, T., and Yoshino, T (Ed) The Fishes of the Japanese Archipelago, Tokai University Press, Tokyo, pp. 236-289, pls. 235-258, 353-355.

Birdsong, R.S., Murdy, E.O. \& Pezold, F.L. (1988) A study of the vertebral column and median fin osteology in gobioid fishes with comments on gobioid relationships. Bulletin of Marine Science, 42, 174-214.

Bleeker, P. (1852) Diagnostische beschrijvingen van nieuwe of weinig bekende vischsoorten van Sumatra. Tiental I-IV. Natuurkundig Tijdschrift voor Nederlandsch Indië, 3, 569-608.

Bleeker, P. (1853) Nieuwe tientallen diagnostische beschrijvingen van nieuwe of weinig bekende vischsoorten van Sumatra. Natuurkundig Tijdschrift voor Nederlandsch Indië, 5, 495-534.

Böhlke, J.B. (1953) A catalogue of the type specimens of Recent fishes in the Natural History Museum of Stanford University. Stanford Ichthyological Bulletin, 5, 1-168.

Chen, I.-S. \& Fang, L.-S. (1999) The Freshwater and Estuarine Fishes of Taiwan, National Museum of Marine Biology \& Aquarium, Pingtung, 287 pp.

Eschmeyer, W.E. (1998) Catalog of Fishes, California Academy of Sciences, San Francisco, 2905 pp.

Fowler, H.W. (1935) Zoological results of the third De Schauensee Siamese Expedition, Part VI.Fishes obtained in 1934. Proceedings of the Academy of Natural Sciences of Philadelphia, 87, $89-163$.

Franz, V. (1910) Die Japanischen Knochenfische der Sammlungen Haberer und Doflein. (Beiträge zur Naturgeschichte Ostasiens.). Abhandlungen. Akademie der Wissenschaften Munchen. Mathematisch-Physikalische Klasse, 4, 1-135.

Herre, A.W.C.T. (1927) Gobies of the Philippines and the China Sea. Monograph of the Bureau of Science, Manila, 23, $352 \mathrm{pp}$.

Hora, S.L. (1923) Fauna of the Chilka Lake. Fish, part V. Memoirs of the Indian Museum, 5, 737769.

Hora, S.L. (1924) Notes on fishes in the Indian Museum. VI. On a new genus of gobioid fishes (subfamily Trypaucheninae) with notes on related forms. Records of the Indian Museum, Calcutta, 26, 155-163.

Kottelat, M., Whitten, A.J., Kartikasari, S.N., \& Wirjoatmodjo, S. (1993) Freshwater Fishes Of Western Indonesia And Sulawesi. Wildlife Heritage Trust of Sri Lanka, Colombo, 259 pp.

Koumans, F.P. (1931) A preliminary revision of the genera of the gobioid fishes with united ventral fins. Proefschrift, Lisse, 174 pp.

Koumans, F.P. (1940) Results of a reexamination of types and specimens of gobioid fishes, with notes on the fishfauna [sic] of the surroundings of Batavia. Zoologische Mededeelingen (Leiden) 22, 121-210.

Koumans, F.P. (1941) Gobioid fishes of India. Memoirs of the Indian Museum, 13, 205-329. 
Koumans, F.P. (1953) Gobioidea. In: M. Weber and L.F. de Beaufort. Fishes of the Indo-Australian Archipelago, vol. 10. E.J. Brill: Leiden, 423 pp.

Larson, H.K., \& Williams, R.S. (1997) Darwin Harbour fishes: a survey and annotated checklist. In: Hanley, J.R., Caswell, G., Megirian, D. \& Larson, H.K. (Ed) Proceedings of the Sixth International Marine Biological Workshop. The Marine Flora and Fauna of Darwin Harbour, Northern Territory, Australia. Museum \& Art Galleries Northern Territory \& Australian Marine Science Association, pp. 339-380.

Leviton, A.E., Gibbs, R.H., Heal, E. \& Dawson, C.E. (1985) Standards in herpetology and ichthyology: part 1. Standard symbolic codes for institutional resource collections in herpetology and ichthyology. Copeia 1985, 802-832.

McCulloch, A.R. \& Ogilby, J.D. (1919) Some Australian fishes of the family Gobiidae. Records of the Australian Museum, 12, 193-291.

Murdy, E.O. (1989) A taxonomic revision and cladistic analysis of the oxudercine gobies (Gobiidae: Oxudercinae). Records of the Australian Museum, Supplement 11, 1-93.

Murdy, E.O. (2002) Karsten, a new genus of eel goby (Gobiidae: Amblyopinae) with a key to "Trypauchen" group genera. Copeia, 2002, 787-791.

Murdy, E.O. \& Shibukawa, K. (2001) A revision of the gobiid fish genus Odontamblyopus (Gobiidae: Amblyopinae). Ichthyological Research, 48, 31-43.

Murdy, E.O. \& Shibukawa, K. (2002) A redescription of the gobiid fish genus Pseudotrypauchen (Gobiidae: Amblyopinae) and its significance in amblyopine phylogeny. Marine and Freshwater Research, 53, 253-258.

Roxas, H.A. \& Ablan, G.L. (1940) New Philippine gobioid fishes. Philippine Journal of Science, 73, 301-311.

Saville-Kent, W. (1889) Preliminary observations on a natural history collection made in connection with the surveying cruise of H. M. S. "Myrmidon," at Port Darwin and Cambridge Gulf September to November, 1888. Proceedings of the Royal Society of Queensland, 6, 219-240. [Fishes are treated on pp. 220-224, 234-237, 239-240.]

Smith, H.M. (1945) The fresh-water fishes of Siam, or Thailand. Bulletin of the U. S. National Museum, 188, 1-622.

Smith, H.M. \& Seale, A. (1906) Notes on a collection of fishes from the island of Mindanao, Philippine Archipelago, with descriptions of new genera and species. Proceedings of the Biological Society of Washington, 19, 73-82. 